\title{
New records and morphometry of the Atlantic sixgill shark Hexanchus vitulus in the Caribbean coast of Guatemala
}

\author{
Cristopher G. Avalos-Castillo ${ }^{1}$, Omar Santana-Morales ${ }^{1,2}$ \\ Edgar E. Becerril-García ${ }^{3}$ \& Elisa Areano ${ }^{1}$ \\ ${ }^{1}$ Fundación Mundo Azul, Ciudad de Guatemala, Guatemala \\ ${ }^{2}$ Facultad de Ciencias Marinas, Universidad Autónoma de Baja California, Ensenada, México \\ ${ }^{3}$ Instituto Politécnico Nacional, Centro Interdisciplinario de Ciencias Marinas, La Paz, México \\ Corresponding author: Edgar E. Becerril-García (bg.ragde@gmail.com)
}

\begin{abstract}
The present study constitutes the first records and morphometry of Hexanchus vitulus on the Caribbean coast of Guatemala. A total of 10 Atlantic six-gill sharks were captured by artisanal fishers during 2015-2019, showing a sex ratio of 2.3:1 (males:females) and a total length that ranges 61-165 cm. Morphometric measurements are provided for future comparisons in other coastal regions. Recorded sharks corresponded mostly to sexually mature individuals, which differs from that reported for different areas of the Caribbean.
\end{abstract}

Keywords: Hexanchiformes; measurements; distribution; segregation; deep-sea species; Central America

The Atlantic sixgill shark Hexanchus vitulus Springer \& Waller, 1969 is one of the three species of the genus Hexanchus, along with the bluntnose sixgill shark $H$. griseus (Bonnaterre, 1788) and the bigeye sixgill shark H. nakamurai Teng, 1962 (Compagno et al., 2005; Daly-Engel et al., 2019). In previous decades, both $H$. nakamurai and $H$. vitulus were recognized as the same species; however, recent genetic studies have suggested the divergence between both taxa (Ebert et al., 2013; Daly-Engel et al., 2019). In the Caribbean Sea, the knowledge of $H$. vitulus and other deep-sea sharks is scarce, as these species were infrequently captured by local artisanal fishers, and therefore scientific research regarding its biology has not been developed (HacohenDomené et al., 2016, 2017). Although there are occasional records of $H$. vitulus in Belize (Daly-Engel et al., 2019), Colombia (Mejía-Falla \& Navia, 2019), Venezuela (Ehemann et al., 2019), and the Dutch Caribbean (Van Beek et al., 2012), there is no information about its presence in Guatemalan waters or its morphometry in any locality of the Caribbean Sea. The present study aims to report the first records with morphometry data of $\mathrm{H}$. vitulus in Guatemala to provide useful information for future comparisons with specimens caught in other regions.
A total of 10 sixgill sharks were captured $80 \mathrm{~km}$ offshore the port of El Quetzalito $\left(15^{\circ} 44^{\prime} 25^{\prime \prime} \mathrm{N}\right.$; $88^{\circ} 16^{\prime} 27^{\prime \prime} \mathrm{W}$ ) by artisanal Guatemalan fishers (Fig.1). The date of capture, fishing gear, used bait, sex, total length (TL), precaudal length (PL), and fork length (FL) were registered from each shark (Table 1). Taxonomic identification was carried out by the descriptions published by Compagno et al. (2005) and Daly-Engel et al. (2019).

All the specimens were identified as $H$. vitulus due to the presence of six gills, a slender body with brown dorsal and white ventral coloration, narrow head and mouth, anterior serrations on lower teeth, and large eyes (Compagno et al., 2005; Fig. 2). These characteristics are the same described for $H$. nakamurai, as $H$. vitulus is considered a cryptic species with no evident external differences (Daly-Engel et al., 2019). The length of the specimens ranged between $61-165 \mathrm{~cm}$ TL, with a mean of $142 \pm 29 \mathrm{~cm} \mathrm{TL}$. All the captured sharks were mature individuals, except for one juvenile female caught in 2015 (Table 1). The sex ratio was 2.3:1 (males:females), where $90 \%$ of the sharks were mature individuals. Finally, a total of 82 measurements were obtained from the last captured individual caught in June 2019 (Table 2).

Corresponding editor: Leonardo Abitia 


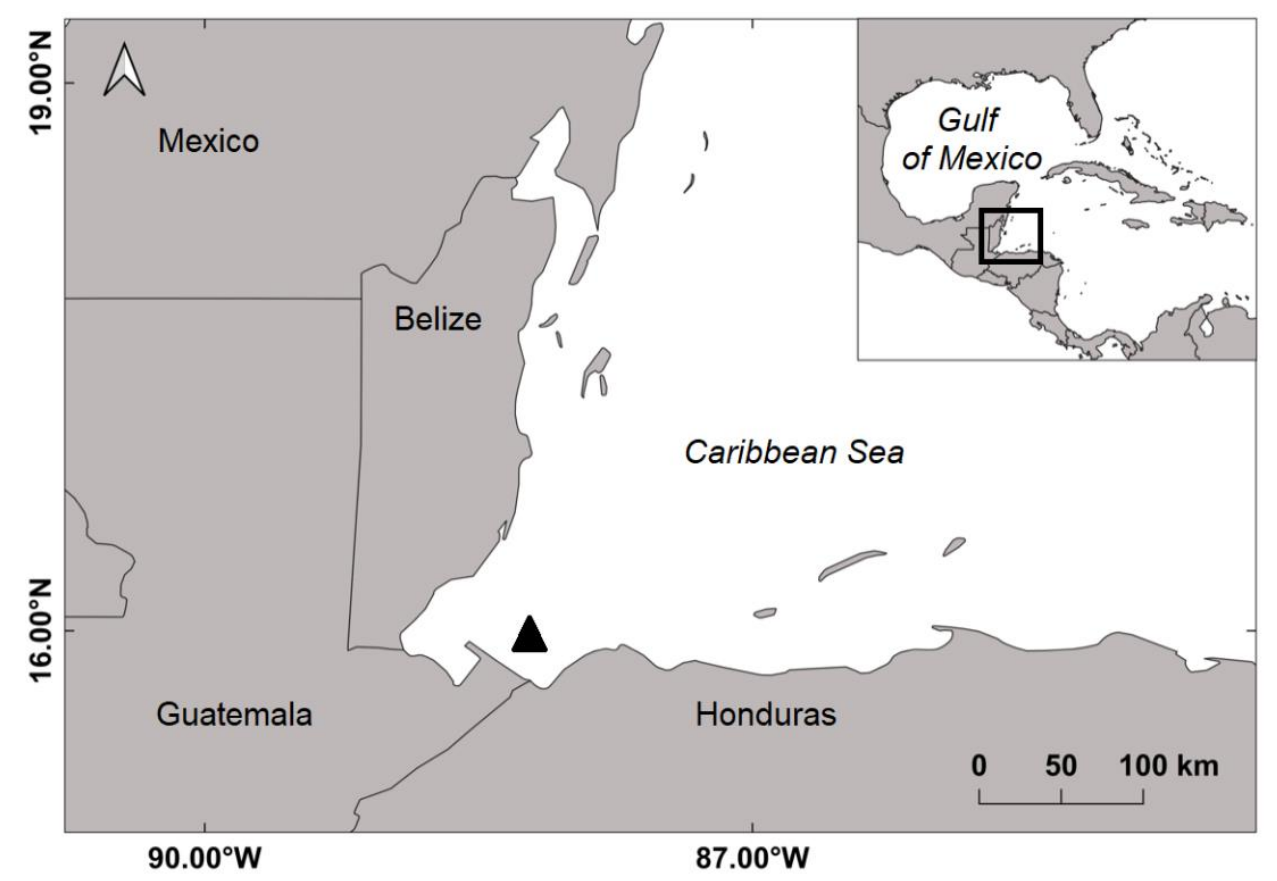

Figure 1. Location site $(\boldsymbol{\Lambda})$ where the specimens of Hexanchus vitulus were captured in the Guatemalan Caribbean during 2015-2019.

Table 1. Records of Hexanchus vitulus on the Caribbean coast of Guatemala during 2015-2019. TL: total length; FL: fork length; PL: precaudal length; CL: clasper length. All measurements are reported in centimeters.

\begin{tabular}{lcccccccc}
\hline Date & Fishing gear & Bait & Sex & Maturity & TL & FL & PL & CL \\
\hline $21 / 12 / 2015$ & Gillnet & - & F & Immature & 61 & 45 & 41 & - \\
$20 / 03 / 2016$ & Gillnet & - & M & Mature & 152 & 119 & 110 & 12 \\
$15 / 02 / 2017$ & Longline & Albula vulpes & M & Mature & 144 & 112 & 104 & 14 \\
$23 / 05 / 2017$ & Longline & Megalops atlanticus & F & Mature & 165 & 127 & 117 & - \\
$26 / 05 / 2017$ & Longline & Mixed species & M & Mature & 153 & 126 & 116 & 15 \\
$03 / 03 / 2018$ & Gillnet & - & F & Mature & 147 & 107 & 100 & - \\
$07 / 03 / 2018$ & Longline & Sarda sarda & M & Mature & 148 & 119 & 106 & 15 \\
$02 / 02 / 2019$ & Longline & Sarda sarda & M & Mature & 152 & 116 & 106 & 15 \\
$06 / 06 / 2019$ & Longline & Megalops atlanticus & M & Mature & 150 & 115 & 105 & 16 \\
$06 / 06 / 2019$ & Longline & Megalops atlanticus & M & Mature & 148 & 114 & 104 & 17 \\
\hline
\end{tabular}

The presence of $H$. vitulus in the Caribbean has been recently discussed by Daly-Engel et al. (2019) through the analysis of captured individuals in Belize. In such a study, immature sharks were obtained mostly during August, September and October, at depths of 242-333 $\mathrm{m}$, and temperatures of $13-17^{\circ} \mathrm{C}$. In the present work, the sharks were caught through similar fishing techniques and at a similar depth (270-350 m), but with a high presence of mature individuals during March, May and July. These preliminary observations could suggest those mature individuals may be segregated from immature sharks of northern areas like Belize, which can be related to nursery areas or differences in the feeding sites for each group.
Regarding its trophic ecology, the presence of mature and immature individuals in several areas of the Caribbean could be related to differences in feeding habits according to maturity, as it has been suggested for similar species such as H. griseus (Compagno et al., 2005; Becerril-García et al., 2017). The preference of H. vitulus for benthic fishes and crustaceans could include hunting or scavenging of other prey such as cephalopods, marine mammals, or other elasmobranchs (Compagno et al., 2005). In this manner, a potential ontogenetic dietary shift could be determined through the analysis of stomach contents and stable isotopes analysis. However, these statements are beyond the scope of this paper and should be evaluated for future 


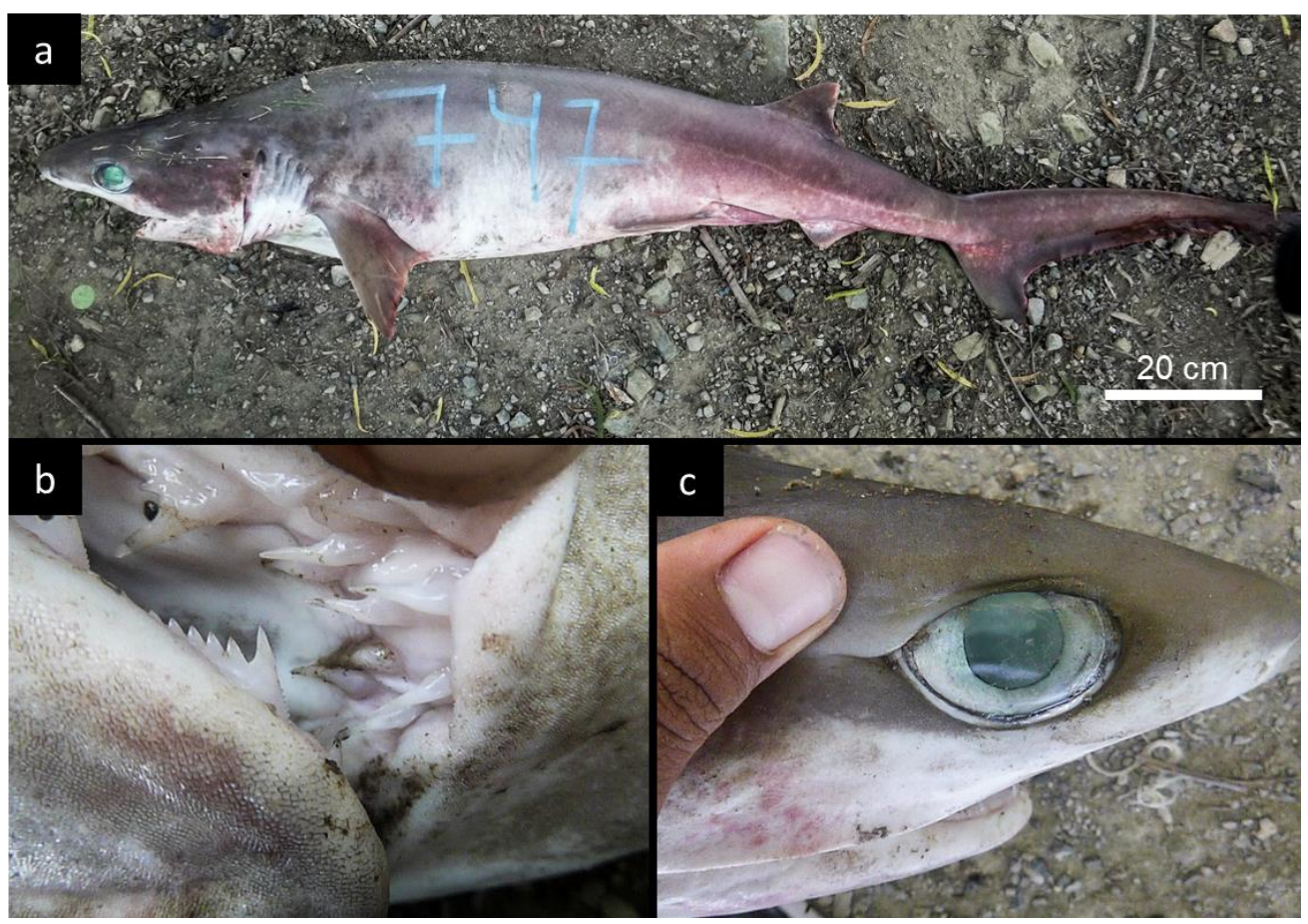

Figure 2. One of the 10 Atlantic sixgill sharks Hexanchus vitulus captured in the Guatemalan Caribbean during 2015-2019; a) full body showing one dorsal fin and six-gill slits, b) upper and lower comb-shaped teeth, c) large eyes.

Table 2. Morphometry (length $(\mathrm{cm})$ and proportion $(\%)$ ) of a mature male of Hexanchus vitulus caught on June 6, 2019 on the Caribbean coast of Guatemala.

\begin{tabular}{lrc}
\hline Measure & $\begin{array}{c}\text { Length } \\
(\mathrm{cm})\end{array}$ & $\begin{array}{c}\text { Proportion } \\
(\%)\end{array}$ \\
\hline Total length & 148 & 100.0 \\
Fork length & 114 & 77.0 \\
Precaudal length & 104 & 70.3 \\
Pre-first dorsal-fin length & 82 & 55.4 \\
Head length & 37 & 25.0 \\
Prebranchial length & 25 & 16.9 \\
Prespiracular length & 20 & 13.5 \\
Preorbital length & 9 & 6.1 \\
Prepectoral-fin length & 32 & 21.6 \\
Prepelvic-fin length & 68.5 & 46.3 \\
Snout-vent length & 74 & 50.0 \\
Preanal-fin length & 90 & 60.8 \\
Dorsal caudal-fin space & 15.7 & 10.6 \\
Pectoral-fin pelvic-fin space & 30.1 & 20.3 \\
Pelvic-fin anal-fin space & 11.7 & 7.9 \\
Anal-fin caudal-fin space & 11.5 & 7.8 \\
Pelvic-fin caudal-fin space & 28.5 & 19.3 \\
Vent caudal-fin length & 60.1 & 40.6 \\
Prenarial length & 2.8 & 1.9 \\
Preoral length & 8 & 5.4 \\
Eye length & 5.3 & 3.6 \\
Eye height & 3 & 2.0 \\
Intergill length & 6.5 & 4.4 \\
First-gill slit height & 13 & 8.8 \\
\hline
\end{tabular}

\begin{tabular}{lrc} 
continuation & & \\
\hline Measure & $\begin{array}{c}\text { Length } \\
(\mathrm{cm})\end{array}$ & $\begin{array}{c}\text { Proportion } \\
(\%)\end{array}$ \\
\hline Second-gill slit height & 10.1 & 6.8 \\
Third-gill slit height & 8.5 & 5.7 \\
Fourth-gill slit height & 8 & 5.4 \\
Fifth-gill slit height & 7.2 & 4.9 \\
Sixth-gill slit height & 6 & 4.1 \\
Pectoral-fin anterior margin & 17 & 11.5 \\
Pectoral-fin base & 8.7 & 5.9 \\
Pectoral-fin inner margin & 7.3 & 4.9 \\
Pectoral-fin posterior margin & 12.8 & 8.6 \\
Pectoral-fin height & 22.7 & 15.3 \\
Pectoral-fin length & 15 & 10.1 \\
Dorsal caudal-fin margin & 43.8 & 29.6 \\
Preventral caudal-fin margin & 14.1 & 9.5 \\
Upper postventral caudal-fin margin & 24.5 & 16.6 \\
Lower postventralcaudal-fin margin & 6.6 & 4.5 \\
Caudal-fin fork width & 11 & 7.4 \\
Caudal-fin fork length & 10.6 & 7.2 \\
Subterminal caudal-fin margin & 5 & 3.4 \\
Subterminal caudal-fin width & 4.5 & 3.0 \\
Terminal caudal-fin margin & 8.3 & 5.6 \\
Terminal caudal-fin lobe & 10.5 & 7.1 \\
First dorsal-fin length & 10.5 & 7.1 \\
First dorsal-fin anterior margin & 9.5 & 6.4 \\
First dorsal-fin base & 8.5 & 5.7 \\
First dorsal-fin height & 5.8 & 3.9 \\
First dorsal-fin inner margin & 3.4 & 2.3 \\
First dorsal-fin posterior margin & 7 & 4.7 \\
Pelvic-fin length & 22 & 14.9 \\
\hline & & \\
& & \\
& 5.5 & \\
& &
\end{tabular}




\begin{tabular}{lrc} 
continuation & $\begin{array}{r}\text { Length } \\
(\mathrm{cm})\end{array}$ & $\begin{array}{c}\text { Proportion } \\
(\%)\end{array}$ \\
\hline Measure & 7 & 4.7 \\
\hline Pelvic-fin anterior margin & 10 & 6.8 \\
Pelvic-fin base & 5 & 3.4 \\
Pelvic-fin height & 13 & 8.8 \\
Pelvic-fin inner margin & 19 & 12.8 \\
Pelvic-fin posterior margin & 8.3 & 5.6 \\
Anal-fin length & 3.4 & 2.3 \\
Anal-fin anterior margin & 5.3 & 3.6 \\
Anal-fin base & 5 & 3.4 \\
Anal-fin height & 3.6 & 2.4 \\
Anal-fin inner margin & 5.3 & 3.6 \\
Anal-fin posterior margin & 16 & 10.8 \\
Head height & 18 & 12.2 \\
Trunk height & 13 & 8.8 \\
Caudal-fin peduncle height & 5 & 3.4 \\
Second dorsal-fin origin anal-fin origin & 8.5 & 5.7 \\
pelvic-fin midpoint second dorsal-fin origin & 10.3 & 7.0 \\
Mouth length & 17 & 11.5 \\
Mouth width & 1.5 & 1.0 \\
Internarial space & 0.5 & 0.3 \\
Anterior nasal-flap length & 8 & 5.4 \\
Clasper outer length & 17 & 11.5 \\
Clasper inner length & 3.7 & 2.5 \\
Clasper base width & 11.5 & 7.8 \\
Interorbital space & 0.5 & 0.3 \\
Spiracle length & 5.5 & 3.7 \\
Eye spiracle space & 18 & 12.2 \\
Head width & 29 & 19.6 \\
Trunk width & 8.9 & 6.0 \\
Tail width & 4 & 2.7 \\
Caudal-fin peduncle width & & \\
\hline & 5 & \\
& &
\end{tabular}

studies regarding deep-sea elasmobranchs of the Caribbean Sea.

Future research related to the biodiversity of elasmobranchs in the Caribbean should include the use of non-lethal techniques, such as baited remote underwater video or environmental DNA analysis at different localities, depths and months (Hacohen-Domené et al., 2017; Daly-Engel et al., 2019), which could be useful to provide some insights about environmental conditions effects on elasmobranch's ecology. Artisanal fishers and deep-sea fisheries could increase in the area for the economic exploitation of sea bottom resources (Daly-Engel et al., 2019).

\section{ACKNOWLEDGMENTS}

We thank the fishers from El Quetzalito, Josue Ayala, and Francisco Polanco-Vásquez for all the provided support. EEBG thanks the Consejo Nacional de Ciencia y Tecnología for the scholarships provided, and D. Bernot-Simon for the English review. This work was conducted under the following permit from Consejo Nacional de Áreas Protegidas de Guatemala (I-DRNO002-2016).

\section{REFERENCES}

Becerril-García, E.E., Aguilar-Cruz, C.A., Jiménez-Pérez, A.A. \& Galván-Magaña, F. 2017. New record and morphometry of the bluntnose sixgill shark Hexanchus griseus (Chondrichthyes: Hexanchidae) in Baja California Sur, Mexico. Latin American Journal of Aquatic Research, 45(4): 833-836.

Compagno, L., Dando, M. \& Fowler, S. 2005. Sharks of the world. Princeton University Press, New Jersey.

Daly-Engel, T.S., Baremore, I.E., Grubbs, R.D., Gulak, S.J., Graham, R.T. \& Enzenauer, M.P. 2019. Resurrection of the sixgill shark Hexanchus vitulus Springer \& Waller, 1969 (Hexanchiformes, Hexanchidae), with comments on its distribution in the northwest Atlantic Ocean. Marine Biodiversity, 49(2): 759-768.

Ebert, D.A., White, W.T. \& Ho, H.C. 2013. Redescription of Hexanchus nakamurai Teng 1962, (Chondrichthyes: Hexanchiformes: Hexanchidae), with designation of a neotype. Zootaxa, 3752(1): 20-34. doi: 10.11646/zootaxa.3752.1.4

Ehemann, N.R., González-González, L.D., Tagliafico, A. \& Weigmann, S. 2019. Updated taxonomic list and conservation status of chondrichthyans from the exclusive economic zone of Venezuela, with first generic and specific records. Journal of Fish Biology, 95(3): 753-771. doi: 10.1111/jfb.14061

Hacohen-Domené, A., Polanco-Vásquez, F. \& Graham, R.T. 2016. First report of the white saddled catshark Scyliorhinus hesperius (Springer 1966) in Guatemala's Caribbean Sea. Marine Biodiversity Records, 9(1): 101. doi: 10.1186/s41200-016-0103-9

Hacohen-Domené, A., Polanco-Vásquez, F. \& Graham, R.T. 2017. First record of Heptranchias perlo (Bonnaterre 1788) in Guatemala's Caribbean Sea. Marine Biodiversity Records, 10(1): 12. doi: 10.1186/ s41200-017-0118-x

Mejía-Falla, P.A. \& Navia, A.F. 2019. Checklist of marine elasmobranchs of Colombia. Universitas Scientiarum, 24(1): 241-276. doi: 10.11144/Javeriana.SC24-1.come

Van Beek, I.J.M., Debrot, A.O. \& De Graaf, M. 2012. Elasmobranchs in the Dutch Caribbean: current population status, fisheries and conservation. IMARES, Wageningen University Research, 12 pp. 